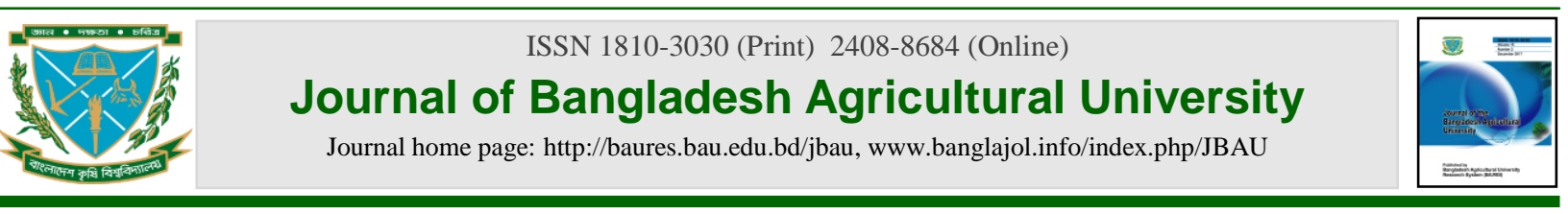

\title{
Nutrient dynamics in paddy soil under rice culture mesocosm studies
}

\author{
M. A. Islam ${ }^{1}$, M. A. Khan ${ }^{2}$ and M. A. Rouf ${ }^{3}$ \\ ${ }^{1}$ Biotechnology Division, Bangladesh Institute of Nuclear Agriculture, Mymensingh- 2202 \\ ${ }^{2}$ Department of Soil Science, Sher-e-Bangla Agricultural University, Dhaka-1207 \\ ${ }^{3}$ Adaptive Research and Extension Division, Bangladesh Institute of Nuclear Agriculture, Mymensingh- 2202
}

\begin{tabular}{|c|c|}
\hline ARTICLE INFO & Abstract \\
\hline $\begin{array}{l}\text { Article history: } \\
\text { Received: } 18 \text { October } 2017 \\
\text { Accepted: } 21 \text { November } 2017\end{array}$ & $\begin{array}{l}\text { The objectives of this study were to determine the nutrient losses through the soil columns with the } \\
\text { variation of soil and fertilizer. The experiment was conducted in a net house of Sher-e-Bangla Agricultural } \\
\text { University, Dhaka, Bangladesh during July-November to study the effect of fertilizer and manure on the } \\
\text { growth and yield of T. aman rice and leaching loss of nutrients through undisturbed soil columns. The }\end{array}$ \\
\hline $\begin{array}{l}\text { Keywords: } \\
\text { Fertilizer, manure, soil column, } \\
\text { T. aman rice, leaching }\end{array}$ & $\begin{array}{l}\text { Sonargaon Soil) with } 4 \text { levels of fertilization, as } \mathrm{F}_{0} \text { : Control, } \mathrm{F}_{1}: 100 \% \mathrm{~N}_{120} \mathrm{P}_{20} \mathrm{~K}_{45} \mathrm{~S}_{20} \text { (FRG 2012), } \mathrm{F}_{2}: 50 \% \\
\text { NPKS }+5 \text { t/ha cowdung, } \mathrm{F}_{3}: 50 \% \text { NPKS }+2.1 \mathrm{t} / \text { ha poultry manure were used in the experiment. T. Aman } \\
\text { (BR11) rice was grown in the soil cores. Altogether, there were } 8 \text { treatment combinations and the } \\
\text { treatment combinations were replicated } 3 \text { times. Twenty four undisturbed soil cores collected in PVC }\end{array}$ \\
\hline $\begin{array}{l}\text { Correspondence: } \\
\text { M. A. Khan } \\
\text { (makhan_sau@ymail.com ) }\end{array}$ & $\begin{array}{l}\text { was connected to a conical flask that was used to collect column leachate. Leachates were collected at } 25 \text {, } \\
35,45,55,65 \text { and } 75 \mathrm{DAT} \text { (Days after transplanting) and analyzed for } \mathrm{N}, \mathrm{P}, \mathrm{K} \text { and } \mathrm{S} \text {. The leachate } \mathrm{N}, \mathrm{P} \text {, } \\
\mathrm{K} \text { and } \mathrm{S} \text { concentration varied with different soil, fertilizer and time. The higher } \mathrm{N} \text { and } \mathrm{S} \text { concentrations } \\
\text { were found in the leachate of SAU soil and higher leachate } \mathrm{K} \text { concentrations were obtained in Sonargaon } \\
\text { soil. The higher amounts of } \mathrm{N} \text { leaching were observed during } 45-55 \mathrm{DAT} \text { and higher leachate } \mathrm{N} \\
\text { concentrations were found in } \mathrm{F}_{1} \text { treatment. Higher leachate } \mathrm{K} \text { concentrations were found in } 100 \% \\
\text { chemical fertilizer treatment and higher leachate } \mathrm{K} \text { concentrations were found at } 35 \mathrm{DAT} \text { in all fertilizer } \\
\text { treatments. The leachate } \mathrm{P} \text { concentration increased at } 35 \mathrm{DAT} \text { and then decreased. Results revealed that } \\
\text { soil had no significant effect on the yield and yield parameters. The yield contributing characters and } \\
\text { yields were significantly affected by fertilizer and manure application. The highest effective tillers } / \text { core } \\
(17.0) \text {, plant height }(105.6 \mathrm{~cm}) \text {, panicle length }(23.70 \mathrm{~cm}) \text {, grain yield }(0.046 \mathrm{~kg} / \mathrm{core}) \text { and straw yield } \\
\left(0.053 \mathrm{~kg} / \text { core) of } \mathrm{T} \text {. Aman rice were found from } \mathrm{F}_{1}(\mathrm{RDCF}) \text { treatment. The highest } 1000 \text {-grain wt. }(23.70\right. \\
\mathrm{g} \text { ) was obtained from } \mathrm{F}_{2} \text { and filled grain/panicle }(121.8) \text { from } \mathrm{T}_{3} \text { treatment and the lowest in } \mathrm{F}_{0} \text { treatment. } \\
\text { The highest grain yield was found by the application of recommended dose of chemical fertilizer which } \\
\text { was statistically similar to } \mathrm{F}_{3}(50 \% \text { NPKS }+2.1 \text { ton poultry manure) treatment. The combined effects of } \\
\text { soil and fertilizer were not significant but the highest grain }(0.049 \mathrm{~kg} / \mathrm{core}) \text { and straw yields }(0.056 \\
\left.\mathrm{kg} / \mathrm{core}) \text { were recorded from } \mathrm{S}_{2} \mathrm{~F}_{1} \text { (Sonargaon Soil }+100 \% \mathrm{NPKS}\right) \text { treatment combination. }\end{array}$ \\
\hline
\end{tabular}

\section{Introduction}

Rice-rice cropping system is the most important cropping system in Bangladesh covering more than $75 \%$ of the total cultivable land. Continuous cultivation of this highly exhaustive cropping sequence in most of the irrigated fertile lands causing decline of soil physiochemical condition in general and soil organic matter (SOM) depletion in particular. Moreover, increasing land use intensity has accelerated a great nutrient depletion in the soils of Bangladesh. It will, therefore, be necessary to place greater emphasis on strategic research to increase the efficiency of applied nutrients through the integration of organic manures, which will help in accomplishing twin objectives of sustaining soil health and ensuring food security and environmental protection.

Application of manures and fertilizers has tremendous effects on the nutrient dynamics in soil. The available nutrient moves downward with percolated water. The bioavailability and movement of nutrients in soil are dependent on a number of factors including the sources and concentrations of the nutrient, soil properties such as clay content, $\mathrm{pH}$ and redox conditions, ions and type and amount of SOM. The efficiency of applied fertilizers in the rice field is greatly affected by the level of soil moisture during rice growing periods. SOM decomposition and nutrients mineralization are also greatly affected by the soil moisture level. Anaerobic condition in paddy soil leads to mobilization of some nutrients and thus affects nutrients bio availability to rice plants.

The transport of N, P, K and S in soil is governed by the difference of soil and the variation of added fertilizer. Application of chemical fertilizers with farmyard manure increase N,P and $\mathrm{K}$ uptake by rice plants and increase 1000 grain weight and grain yield of rice (Yang et al., 2004). The mobility of N, P, K and S in soil is still not thoroughly understood. The preferential flow of $\mathrm{K}$ in the undisturbed soil cores due to lack of $\mathrm{K}$ sorption (Jalali and Rowell, 2009). Anderson and Magdoff (2005) 
found that repeated application of organic forms of $\mathrm{P}$ could lead to significant leaching of $\mathrm{P}$ to ground water.

Little is known on the fate of applied fertilizer and manure during rice culture through undisturbed soil columns. To increase the efficiency of manure and fertilizer in rice cultivation, it is necessary to know the suitable level and type of manure and fertilizer. The fate of added fertilizer in the soil column and estimation of nutrient leaching will be worthy. The study was undertaken to understand the effect of manure and fertilizer on yield and leaching loss of nutrients through soil columns in rice culture system.

\section{Materials and Methods}

An experiment was carried out in a net house of Sher-eBangla Agricultural University during the T. Aman season (July to November) to evaluate the nutrient dynamics in undisturbed paddy soil columns with rice culture. The climate of the experimental area is characterized by high temperature, high humidity and medium rainfall with occasional gusty winds during the season. Two soils were collected in poly vinyl choride (PVC) pipes from the SAU farm, Dhaka and Farmers field, Sonargaon, Narayanganj during July, 2011. Twenty four (2 soils x 4 fertilizer application $\mathrm{x} 3$ replication) undisturbed soil cores $(25 \mathrm{~cm}$ diameter and $40 \mathrm{~cm}$ length) were collected in PVC pipes. Initial soil samples were collected from each site and analyzed for physio-chemical properties. The PVC pipes were pushed into the soil by creating pressure inside pipe wall and by adding water in the soil. The soil cores were carried to the net house and were placed in the plastic container. Filter paper (Whatman No. 1), glass wool and a $4-\mathrm{cm}$ layer of acid-washed silica sand (1-2 $\mathrm{mm}$ diameter) were placed at the bottom of the plastic container that served as the base for the PVC soil core. Two holes in the plastic base were connected by means of polypropylene tubes and a $\mathrm{T}$ tube to a air-tight conical flask to collect leachate (Fig. 1). Two soils (Soil-1: SAU Soil, Soil-2: Sonargaon Soil) and four fertilizer treatments $\left(\mathrm{F}_{0}\right.$ : Control $\mathrm{F}_{1}$ : $\left(\mathrm{N}_{120} \mathrm{P}_{20} \mathrm{~K}_{45} \mathrm{~S}_{20}\right)$ (FRG 2012), $\mathrm{F}_{2}: 50 \% \mathrm{NPKS}+5 \mathrm{t} /$ ha cowdung, $\mathrm{F}_{3}: 50 \% \mathrm{NPKS}+2.1$ $\mathrm{t} /$ ha poultry manure) were used for rice cultivation in the PVC cores. The treatment wise required amounts of manures and $\mathrm{N}, \mathrm{P}, \mathrm{K}$ and $\mathrm{S}$ fertilizers per core were applied by acre furrow slice based calculation. Full amounts of manure, TSP, MoP and gypsum were applied at final land preparation before transplanting. Urea was applied in 3 equal splits: one third was applied as basal dose before transplanting, one third at active tillering stage (30 DAT) and the remaining one third was applied at 5 days before panicle initiation stage (55 DAT). Chemical compositions of the soils and manures used have been presented in (Table $1 \& 2$ ).

BR11 was used as the test crop in this experiment. The experimental design was Complete Randomized Design (CRD) with two factors and three replicates for each treatment. The distance maintained between core to core and row to row were $40 \mathrm{~cm}$ and $1 \mathrm{~m}$ respectively. Thirty days old T.Aman seedlings of BR11 were transplanted on the 1st week of July. Two seedlings were used in each hill and one hill/ soil core. Traditional irrigation (2$3 \mathrm{~cm}$ continuous flooding) was applied during the growing period of T.Aman rice crop. Intercultural operations and plant protection measures were done to ensure normal growth of the crop. Leachates were collected at 25, 35, 45, 55, 65 and 75 DAT of T. Aman rice and analyzed for $\mathrm{N}, \mathrm{P}, \mathrm{K}$ and $\mathrm{S}$ by using standard analytical methods. The crop was harvested at full maturity when $80-90 \%$ of the grains were turned into straw color. The crop was cut at ground level. After harvest, the rice yield parameters and yield were recorded.

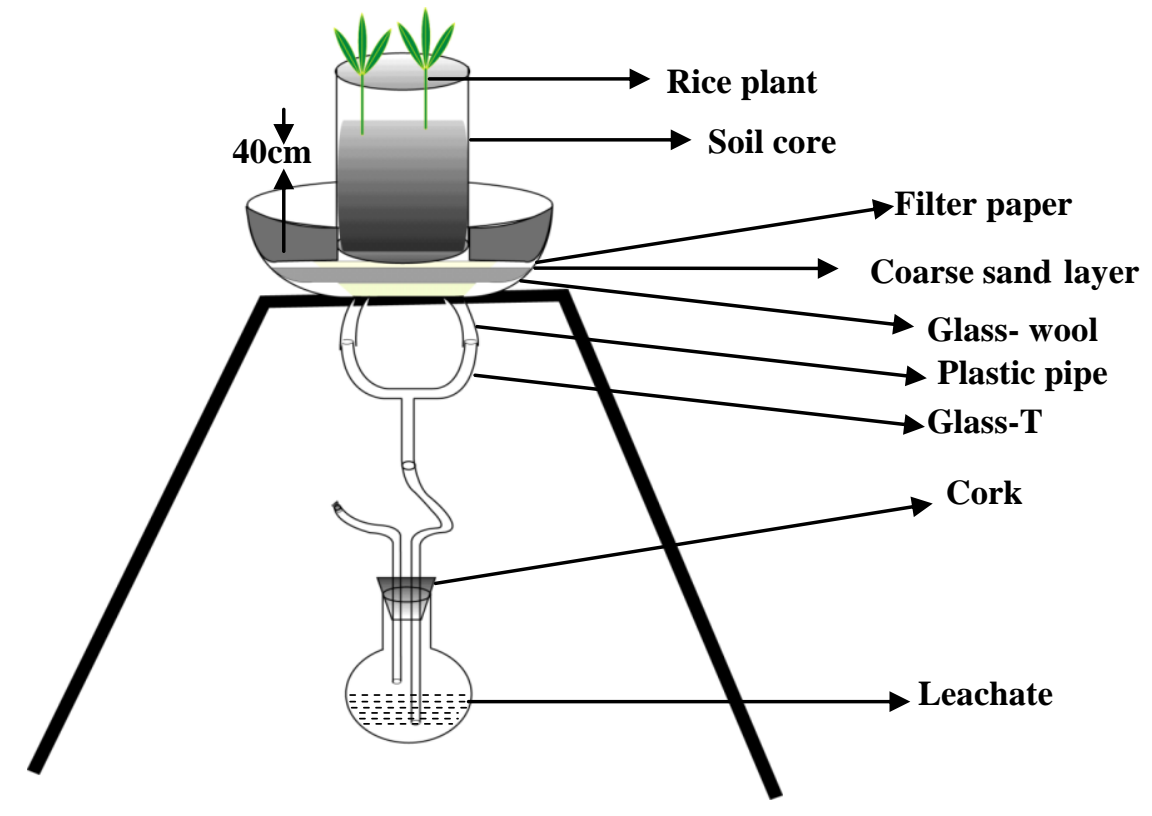

Fig. 1. Leachate collection from undisturbed soil core with fertilizer and manure application in T. Aman rice 
Table 1. Physicochemical properties of initial soils $(0-15 \mathrm{~cm})$ of SAU and Sonargaon

\begin{tabular}{lcc}
\hline \multicolumn{1}{c}{ Characteristics } & SAU Soil & Sonargaon Soil \\
\hline Textural class & Silt Loam & Silty clay loam \\
$\mathrm{pH}$ & 6.4 & 7.3 \\
Organic C (\%) & 0.69 & 1.01 \\
Total N (\%) & 0.062 & 0.073 \\
Exchangeable K $\left(\mathrm{cmolckg}^{-1}\right)$ & 0.12 & 0.23 \\
Available P $\left(\mathrm{mg} \mathrm{kg}^{-1}\right)$ & 19.85 & 12.00 \\
Available S $\left(\mathrm{mg} \mathrm{kg}^{-1}\right)$ & 14.40 & 16.00 \\
\hline
\end{tabular}

Table 2. Nutrient levels in cowdung and poultry manure (oven dry basis)

\begin{tabular}{ccccc}
\hline Organic Manure & \multicolumn{4}{c}{ Nutrient content (\%) } \\
\cline { 2 - 5 } & $\mathrm{N}$ & $\mathrm{P}$ & $\mathrm{K}$ & $\mathrm{S}$ \\
\hline Cowdung & 1.46 & 0.29 & 0.74 & 0.24 \\
Poultry manure & 2.2 & 1.99 & 0.82 & 0.29 \\
\hline
\end{tabular}

\section{Soil and leachate analysis}

Soil samples were analyzed for both physical and chemical characteristics viz. texture, $\mathrm{pH}$, total $\mathrm{N}$ and available $\mathrm{P}, \mathrm{K}$, and $\mathrm{S}$ contents. The leachate samples were analyzed for $\mathrm{N}, \mathrm{P}, \mathrm{K}$ and $\mathrm{S}$ concentrations. Mechanical analysis of soil were done by hydrometer method (Bouyoucos, 1926) and the textural class was determined by plotting the values of $\%$ sand, $\%$ silt and $\%$ clay in the Marshall's triangular co-ordinate following the USDA system. Soil $\mathrm{pH}$ was determined by glass electrode $\mathrm{pH}$ meter (Jackson, 1962). The organic carbon was determined by wet-oxidation method (Walkley and Black, 1935). Total $\mathrm{N}$ of soil was determined by the Micro Kjeldahl method. One g of oven dry ground soil sample was taken into a micro Kjeldahl flask to which $1.1 \mathrm{~g}$ catalyst mixture $\left(\mathrm{K}_{2} \mathrm{SO}_{4}: \mathrm{CuSO}_{4} \cdot 5 \mathrm{H}_{2} \mathrm{O}\right.$ : $\mathrm{Se}$ in the ratio of 100: 10: 1), and $7 \mathrm{ml} \mathrm{H}_{2} \mathrm{SO}_{4}$ were added. The flasks were swirled and heated $160^{\circ} \mathrm{C}$ and added $2 \mathrm{ml}$ $\mathrm{H}_{2} \mathrm{O}_{2}$ and then heating at $360^{\circ} \mathrm{C}$ was continued until the digest was clear and colorless. After cooling, the content was taken into $50 \mathrm{ml}$ volumetric flask and the volume was made up to the mark with distilled water. A reagent blank was prepared in a similar manner. These digests were used for $\mathrm{N}$ determination (Page et al., 1982). Ten $\mathrm{ml}$ digest was transferred into the distillation flask, 10 $\mathrm{ml}$ of $\mathrm{H}_{3} \mathrm{BO}_{3}$ indicator solution was taken into a $250 \mathrm{ml}$ conical flask which is marked to indicate a volume of 50 $\mathrm{ml}$ and placed the flask under the condenser outlet of the distillation apparatus so that the delivery end dipped in the boric acid. By operating switch of the distillation apparatus the distillate was collected and titrated with $0.01 \mathrm{~N}$ sulphuric acid. Available $\mathrm{P}$ was determined from the soil with $0.5 \mathrm{M} \mathrm{NaHCO}_{3}$ solution, $\mathrm{pH} 8.5$ (Olsen et al., 1954). Exchangeable $\mathrm{K}$ was determined by $1 \mathrm{~N}$ $\mathrm{NH}_{4} \mathrm{OAc}(\mathrm{pH} 7)$ extraction method and by using flame photometer and calibrated with a standard curve. Available $\mathrm{S}$ was extracted by $\mathrm{CaCl}_{2}(0.15 \%)$ solution and determined as described by Page et al. (1982). The leachates were analyzed for available $\mathrm{N}, \mathrm{P}, \mathrm{K}$ and $\mathrm{S}$ by using similar methods. The data obtained for different parameters were statistically analyzed to find the significant difference of different treatments on yield and yield contributing characters of BR11. The mean values of all the characters were calculated and analysis of variance was performed by the ' $F$ ' (variance ratio) test. The significance of the difference among the treatment means was estimated by the Duncan's Multiple Range Test (DMRT) at 5\% level of probability (Gomez and Gomez, 1984).

\section{Results and Discussion}

\section{Leachate $N$ and $K$ concentrations}

The $\mathrm{N}$ concentration in leachate during $\mathrm{T}$. Aman growing period varied with different soils, fertilizer treatments and time. Higher leachate $\mathrm{N}$ concentrations were found during 35 to 45 DAT of rice with different soils and fertilizer treatments. The higher $\mathrm{N}$ concentrations were found in the leachates of SAU $\left(S_{1}\right)$ soil compared to Sonargaon soil $\left(\mathrm{S}_{2}\right)$. The $\mathrm{N}$ leaching increased with time from 25 to 45 days after transplantation of rice may be due to increasing temperature, microbial activity and application of urea in soil. The highest leachate $\mathrm{N}$ concentrations (5.08 ppm) was recorded in SAU soil and that of $4.78 \mathrm{ppm}$ was recorded in Sonargaon soil (Table 3). Higher leachate K concentrations were found in Sonargaon soil compared to SAU soil. The highest leachate K concentration (4.85 ppm) was found at 35 DAT with Sonargaon soil (Table 3). The higher $\mathrm{K}$ leaching was found in the Sonargaon soil may be due to the presence of higher levels of background available $\mathrm{K}$. Higher $\mathrm{K}$ leaching was noticed at 35DAT may be due to the effect of temperature and that date was closer to application of fertilizer. 
Table 3. $\mathrm{N}$ and $\mathrm{K}$ conc. in leachates at different dates of $\mathrm{T}$. Aman rice growing period in two soils

\begin{tabular}{ccccccccccccc}
\hline Soil & \multicolumn{1}{c}{ leachate N $(\mathrm{ppm})$} & \multicolumn{1}{c}{ leachate K $(\mathrm{ppm})$} \\
& \multicolumn{1}{c}{25} & 35 & 45 & 55 & 65 & 75 & 25 & 35 & 45 & 55 & 65 & 75 \\
& DAT & DAT & DAT & DAT & DAT & DAT & DAT & DAT & DAT & DAT & DAT & DAT \\
\hline $\mathrm{S}_{1}$ & 1.87 & $4.25 \mathrm{a}$ & 5.08 & $3.50 \mathrm{a}$ & 3.84 & 2.45 & $0.71 \mathrm{a}$ & 3.61 & $1.07 \mathrm{~b}$ & $0.71 \mathrm{a}$ & 1.81 & 2.87 \\
$\mathrm{~S}_{2}$ & 1.81 & $3.47 \mathrm{~b}$ & 4.78 & $1.93 \mathrm{~b}$ & 3.03 & 2.33 & $1.20 \mathrm{~b}$ & 4.85 & $1.49 \mathrm{a}$ & $1.43 \mathrm{~b}$ & 2.5 & 4.22 \\
$\mathrm{SE}( \pm)$ & NS & 0.27 & NS & 0.43 & NS & NS & 0.07 & NS & 0.12 & 0.06 & 0.49 & 1.02 \\
\hline
\end{tabular}

In a column figure(s) with dissimilar letter differ significantly as per DMRT at 5\% level of significance.

The highest $\mathrm{N}$ concentrations were found in the leachate of $100 \%$ recommended dose of chemical fertilizer $\left(\mathrm{F}_{1^{-}}\right.$ $\mathrm{RDCF})$ and the lowest concentration was observed in the control treatment (Fig. 2). The higher concentrations of $\mathrm{N}$ leaching were observed during 45-55 DAT and highest concentration $(6.18 \mathrm{ppm})$ was found in $\mathrm{F}_{1}$ treatment at 45DAT. Among the fertilizer treatments, higher concentrations of $\mathrm{K}$ were found in the leachate of $100 \%$ chemical fertilizer treatment compared to other fertilizer treatments (Fig. 2). The highest $\mathrm{K}$ concentration $(5.18 \mathrm{ppm})$ in the leachate was found at $35 \mathrm{DAT}$ with $\mathrm{F}_{2}$ treatment and lowest $\mathrm{K}$ concentrations were found from the control. Chemical fertilizer was more leachable from the soil solution but where organic and inorganic fertilizers were added to soil then nutrients were adsorbed to organic colloids and formed complex and leaching of $\mathrm{K}$ was reduced. The highest concentration of $\mathrm{K}$ was found in the leachate of 35 DAT and then almost similar trend was observed. When fertilizer was applied initially more leachable $\mathrm{K}$ was present in the leachate firstly, and after 35 days soluble $\mathrm{K}$ was fixed on the soil colloidal surface.

Combined effect of soil and fertilizer had no significant effect on leachate $\mathrm{N}$ concentrations in different dates but highest leachate $\mathrm{N}$ concentrations was recorded in $\mathrm{S}_{2} \mathrm{~F}_{1}$ (100\% recommended dose of chemical fertilizer applied on Sonargaon soil) treatment at 45 DAT and lowest was found in $\mathrm{S}_{1} \mathrm{~F}_{0}$ (No addition of fertilizer in SAU soil) treatment combination at 25 DAT (Table 4). Due to combined effect of soil and fertilizer, higher (5.79 ppm) concentrations of $\mathrm{K}$ in the leachate were found in the $\mathrm{S}_{2} \mathrm{~F}_{2}$ where $50 \%$ recommended dose of chemical fertilizer plus 5 ton compost/ha was applied in Sonargaon soil. Due to combined application of different soil and fertilizer, the leachate concentration significantly influenced and higher leachate $\mathrm{K}$ concentration was found in the treatment $S_{1} F_{1}$ and $S_{2} F_{1}$ in most of time where $100 \%$ chemical fertilizer was applied on SAU and Sonargaon soils (Table 4). Significant amounts of $\mathrm{K}$ leaching were found in the leachate samples of different days after transplantation with different soils and fertilizer treatment combinations. This K leaching can be minimized by split application or by adopting proper fertilizer management practices.

\section{Leachate $P$ and $S$ concentration}

The $\mathrm{P}$ concentrations in the leachate were not significantly different with different soils and treatment. Higher P concentrations were found in the leachate of 35 and 45 DAT and then declined. Almost similar concentration of $\mathrm{P}$ was found in the leachate of both the soil (Table 5). The leachate $S$ concentrations increased with increasing time upto 75 DAT during the rice growing period in both the soils. Higher $S$ concentrations were found in the leachate of SAU soil compared to Sonargaon soil (Table 5).
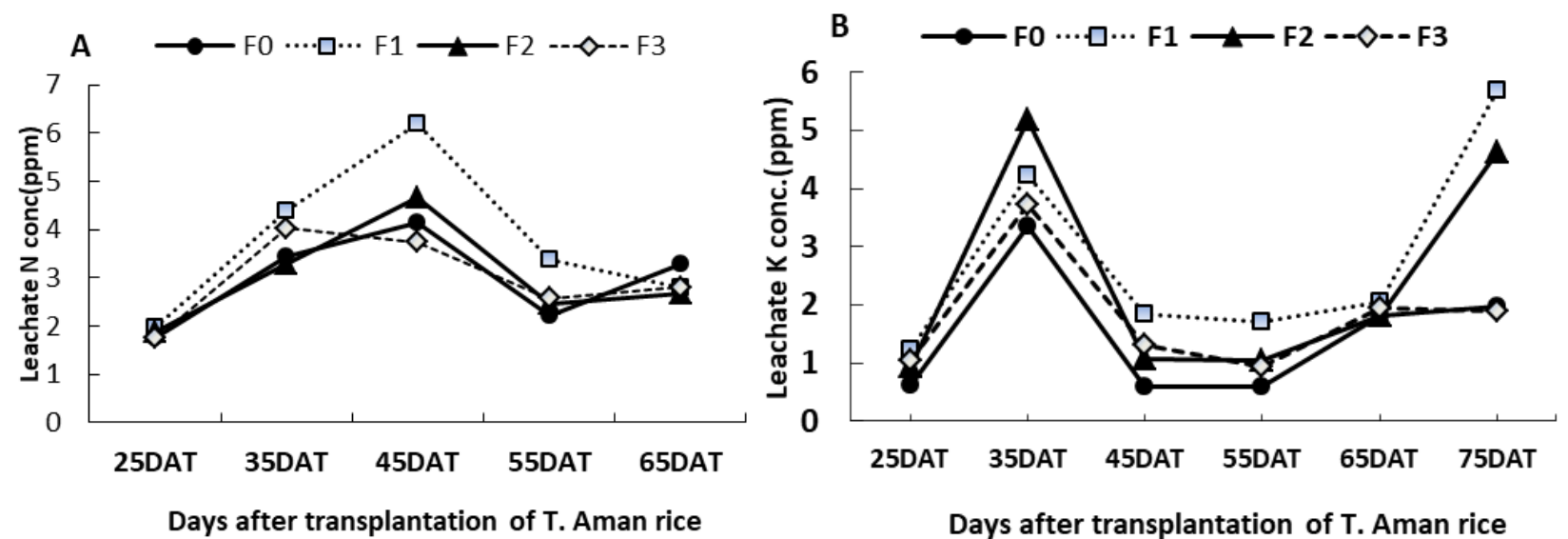

Fig. 2. Effect of fertilizer and manure on $\mathrm{N}$ and $\mathrm{K}$ conc. in the leachate of different dates of T.Aman rice growing period 
Islam et al.

Table 4. Effect of fertilizer and manure with different soils on $\mathbf{N}$ and $\mathrm{K}$ conc. in the leachate of different dates of $\mathbf{T}$. aman rice growing period

\begin{tabular}{|c|c|c|c|c|c|c|c|c|c|c|c|c|}
\hline \multirow{3}{*}{$\begin{array}{c}\text { Treatment } \\
\text { combination }\end{array}$} & \multicolumn{6}{|c|}{ Leachate N (ppm) } & \multicolumn{6}{|c|}{ Leachate K (ppm) } \\
\hline & 25 & 35 & 45 & 55 & 65 & 75 & 25 & 35 & 45 & 55 & 65 & 75 \\
\hline & DAT & DAT & DAT & DAT & DAT & DAT & DAT & DAT & DAT & DAT & DAT & DAT \\
\hline $\mathrm{S}_{1} \mathrm{~F}_{0}$ & $1.40 \mathrm{a}$ & 3.62 & 4.43 & 2.57 & 3.27 & 2.33 & $0.63 c$ & 3.27 & $1.19 \mathrm{ab}$ & 0.33 & 0.77 & 1.67 \\
\hline $\mathrm{S}_{1} \mathrm{~F}_{1}$ & $2.33 b$ & 5.13 & 5.60 & 3.97 & 1.86 & 2.80 & $0.77 \mathrm{c}$ & 3.80 & $1.67 \mathrm{ab}$ & 1.04 & 1.10 & 3.75 \\
\hline $\mathrm{S}_{1} \mathrm{~F}_{2}$ & $2.10 \mathrm{~b}$ & 3.38 & 5.36 & 3.03 & 3.03 & 2.33 & $0.83 b c$ & 4.56 & $0.71 b$ & 0.83 & 2.82 & 4.17 \\
\hline $\mathrm{S}_{1} \mathrm{~F}_{3}$ & $1.80 \mathrm{~b}$ & 4.55 & 4.90 & 3.97 & 2.80 & 1.86 & $0.63 c$ & 2.81 & $0.71 b$ & 0.62 & 2.56 & 1.88 \\
\hline $\mathrm{S}_{2} \mathrm{~F}_{0}$ & $2.10 \mathrm{~b}$ & 3.27 & 5.83 & 1.87 & 3.27 & 2.33 & $1.04 \mathrm{abc}$ & 4.33 & $1.19 \mathrm{ab}$ & 0.83 & 2.82 & 2.29 \\
\hline $\mathrm{S}_{2} \mathrm{~F}_{1}$ & $1.63 \mathrm{ab}$ & 3.62 & 6.77 & 2.80 & 3.73 & 1.63 & $1.46 \mathrm{ab}$ & 4.68 & $1.43 \mathrm{ab}$ & 1.04 & 1.03 & 5.63 \\
\hline $\mathrm{S}_{2} \mathrm{~F}_{2}$ & $1.63 \mathrm{ab}$ & 3.15 & 3.97 & 1.87 & 2.33 & 3.50 & $1.04 \mathrm{abc}$ & 5.79 & $1.43 \mathrm{ab}$ & 2.38 & 2.82 & 5.09 \\
\hline $\mathrm{S}_{2} \mathrm{~F}_{3}$ & $2.10 \mathrm{~b}$ & 3.50 & 2.57 & 1.17 & 2.80 & 2.33 & $1.46 \mathrm{ab}$ & 4.62 & $1.70 \mathrm{a}$ & 1.25 & 3.33 & 1.88 \\
\hline $\mathrm{SE}( \pm)$ & 0.42 & NS & NS & NS & NS & NS & 0.15 & NS & 0.25 & 0.13 & NS & NS \\
\hline
\end{tabular}

In a column figure(s) with dissimilar letter differ significantly as per DMRT at 5\% level of significance.

Table 5. Effect of soils on $P$ and $S$ conc. in the leachate during T.Aman rice growing period

\begin{tabular}{|c|c|c|c|c|c|c|c|c|c|c|c|c|}
\hline \multirow[t]{3}{*}{ Soil } & \multicolumn{6}{|c|}{ Leachate P (ppm) } & \multicolumn{6}{|c|}{ Leachate S (ppm) } \\
\hline & 25 & 35 & 45 & 55 & 65 & 75 & 25 & 35 & 45 & 55 & 65 & 75 \\
\hline & DAT & DAT & DAT & DAT & DAT & DAT & DAT & DAT & DAT & DAT & DAT & DAT \\
\hline$\overline{S_{1}}$ & 0.125 & 1.36 & 0.39 & 0.36 & 0.16 & 0.04 & 3.20 & $0.39 \mathrm{a}$ & 4.08 & 6.89 & 6.76 & 7.26 \\
\hline $\mathrm{S}_{2}$ & 0.158 & 1.22 & 0.42 & 0.32 & 0.11 & 0.08 & 3.35 & $0.19 b$ & 3.85 & 1.36 & 6.06 & 6.21 \\
\hline $\mathrm{SE}( \pm)$ & NS & NS & NS & 0.43 & NS & NS & NS & 0.05 & NS & 0.86 & $\mathrm{NS}$ & NS \\
\hline
\end{tabular}

In a column figures with dissimilar letter differ significantly as per DMRT at $5 \%$ level of significance.

The fertilizer application did not affect the leachate $\mathrm{P}$ concentrations significantly. Higher leachate $P$ concentrations were found in the $F_{1}, F_{2}$ and $F_{3}$ treatments where fertilizer and manure were applied (Fig. 3). The leachate $\mathrm{P}$ concentration increased at 35 DAT and then decreased. Higher $\mathrm{P}$ leaching was noticed at 35DAT may be due to presence of higher orthophosphate in the pore-water initially and decreased solubility for becoming non-labile $\mathrm{P}$ with increasing time. The root growth and increase of microbial population may

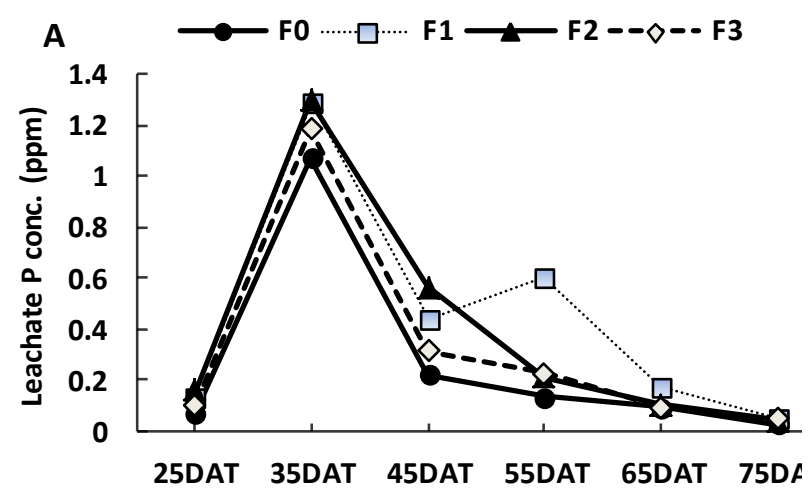

Days after transplantation of T. Aman rice contribute to increase leachate $\mathrm{P}$ concentration. Among the fertilizer treatments, higher levels of $S$ concentrations were recorded in the leachate of two combined treatment where cowdung and poultry manure were used with 50\% chemical fertilizer (Fig. 3). The highest concentration of $8.74 \mathrm{ppm} \mathrm{S}$ was obtained from the $\mathrm{F}_{2}$ treatment where $50 \%$ RDCF and 5 ton cow dung $\mathrm{ha}^{-1}$ were applied. The lowest $\mathrm{S}$ concentration $(0.23$ ppm) was obtained from the control treatment.

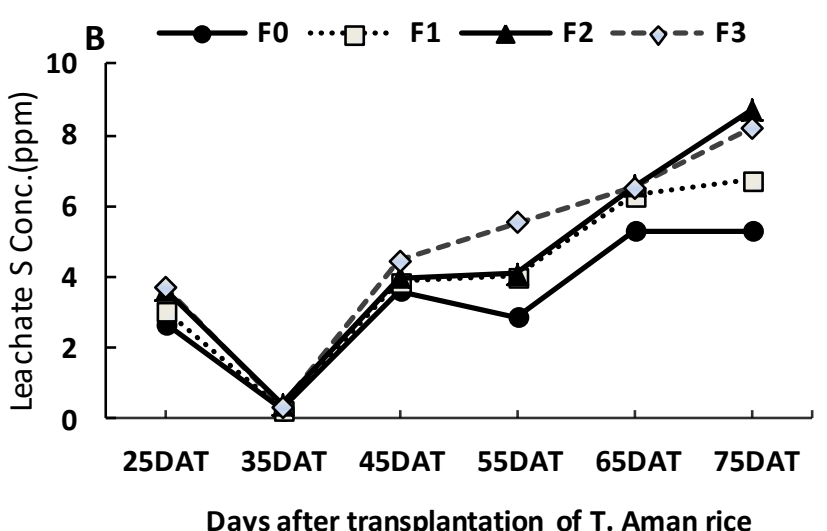

Days after transplantation of T. Aman rice

Fig. 3. Effect of fertilizer and manure on $\mathrm{P}$ and $\mathrm{S}$ conc. in the leachate of different dates of $\mathrm{T}$. Aman rice growing period

The leachate $\mathrm{P}$ concentration was not significantly affected by the interaction effect of fertilizer and soil. The highest $(1.70 \mathrm{ppm})$ leachate $\mathrm{P}$ concentration was found at 35 DAT with $\mathrm{S}_{1} \mathrm{~F}_{2}$ treatment combination and the lowest $(0.82 \mathrm{ppm})$ from $\mathrm{S}_{1} \mathrm{~F}_{3}$ treatment combination (Table 6). The higher leachate $S$ concentrations were found in the combined application of fertilizer and SAU soils. The highest leachate $\mathrm{S}$ concentrations were found in the $\mathrm{S}_{1} \mathrm{~F}_{3}$ treatment combination and lowest from $\mathrm{S}_{2} \mathrm{~F}_{0}$ treatment combination. The presence of higher concentrations of leachate $\mathrm{S}$ over the fertilizer treatments and soils during the growing periods indicated higher mobility and solubility of sulphate in soil. 
Table 6. Interaction effect of fertilizer and manure with different soils on $P$ and $S$ conc. in the leachate of different dates during $T$. aman rice growing period

\begin{tabular}{ccccccccccccc}
\hline Treatment & \multicolumn{4}{c}{ Leachate $\mathrm{P}(\mathrm{ppm})$} & \multicolumn{1}{c}{ Leachate $\mathrm{S}(\mathrm{ppm})$} \\
\cline { 2 - 14 } combination & 25 & 35 & 45 & 55 & 65 & 75 & 25 & 35 & 45 & 55 & 65 & 75 \\
& DAT & DAT & DAT & DAT & DAT & DAT & DAT & DAT & DAT & DAT & DAT & DAT \\
\hline $\mathrm{S}_{1} \mathrm{~F}_{0}$ & 0.08 & 1.19 & 0.23 & 0.18 & 0.03 & 0.02 & 2.69 & 0.23 & 3.36 & 4.21 & 5.79 & 5.87 \\
$\mathrm{~S}_{1} \mathrm{~F}_{1}$ & 0.10 & 1.52 & 0.34 & 0.55 & 0.08 & 0.03 & 3.10 & 0.33 & 4.79 & 5.91 & 6.92 & 7.10 \\
$\mathrm{~S}_{1} \mathrm{~F}_{2}$ & 0.09 & 1.70 & 0.61 & 0.27 & 0.08 & 0.03 & 3.16 & 0.55 & 3.60 & 7.73 & 5.64 & 7.98 \\
$\mathrm{~S}_{1} \mathrm{~F}_{3}$ & 0.09 & 0.82 & 0.29 & 0.25 & 0.15 & 0.04 & 3.84 & 0.43 & 4.58 & 9.70 & 7.66 & 8.10 \\
$\mathrm{~S}_{2} \mathrm{~F}_{0}$ & 0.11 & 0.95 & 0.31 & 0.18 & 0.03 & 0.04 & 2.67 & 0.25 & 3.82 & 1.51 & 5.82 & 2.69 \\
$\mathrm{~S}_{2} \mathrm{~F}_{1}$ & 0.16 & 1.06 & 0.53 & 0.66 & 0.25 & 0.06 & 3.00 & 0.14 & 2.95 & 2.12 & 5.64 & 4.36 \\
$\mathrm{~S}_{2} \mathrm{~F}_{2}$ & 0.23 & 0.90 & 0.52 & 0.24 & 0.12 & 0.04 & 4.14 & 0.20 & 4.31 & 0.45 & 7.44 & 8.51 \\
$\mathrm{~S}_{2} \mathrm{~F}_{3}$ & 0.12 & 1.55 & 0.34 & 0.21 & 0.03 & 0.05 & 3.57 & 0.18 & 4.32 & 1.36 & 5.35 & 7.31 \\
$\mathrm{SE}( \pm)$ & $\mathrm{NS}$ & NS & NS & NS & NS & NS & NS & NS & NS & NS & NS & NS \\
\hline
\end{tabular}

In a column figure(s) with dissimilar letter differ significantly as per DMRT at 5\% level of significance.

Yield parameters

The effects of soils on the effective tillers/core, plant height, panicle length, filled grains panicle ${ }^{1}, 1000$ grain weight, straw and grain yield of rice are presented in Table 7. Results revealed that variation in all the yield parameters and yield of $\mathrm{T}$. aman rice were not significantly different in two different soils. Between these two soils, SAU Soil showed the higher (12.4) number of effective tillers/core, straw yield (0.034 $\mathrm{kg} / \mathrm{core}$ ) and Sonargaon soil showed lower number of effective tillers/core(11.7) and straw yield (0.033 $\mathrm{kg} /$ core). Two soils, showed the similar grain yield $(0.031 \mathrm{~kg} / \mathrm{core})$.

Table 7. Effect of soils on the yield parameters and yield of T. Aman rice

\begin{tabular}{cccccccc}
\hline Soils & $\begin{array}{c}\text { No. effective } \\
\text { tillers/core }\end{array}$ & $\begin{array}{c}\text { Plant } \\
\text { height }(\mathrm{cm})\end{array}$ & $\begin{array}{c}\text { Panicle } \\
\text { length }(\mathrm{cm})\end{array}$ & $\begin{array}{c}\text { No. of filled } \\
\text { grain/panicle }\end{array}$ & $\begin{array}{c}\text { 1000- grain } \\
\text { wt. }(\mathrm{g})\end{array}$ & $\begin{array}{c}\text { Straw yield } \\
(\mathrm{kg} / \mathrm{core})\end{array}$ & $\begin{array}{c}\text { Grain yield } \\
(\mathrm{kg} / \mathrm{core})\end{array}$ \\
\hline $\mathrm{S}_{1}$ & 12.42 & 97.23 & 22.82 & 102.3 & 23.45 & 0.034 & 0.031 \\
$\mathrm{~S}_{2}$ & 11.75 & 99.95 & 23.13 & 107.7 & 23.60 & 0.033 & 0.031 \\
$\mathbf{S E}( \pm)$ & $\mathrm{NS}$ & NS & NS & NS & NS & NS & NS
\end{tabular}

In a column figure(s) with dissimilar letter differ significantly as per DMRT at 5\% level of significance.

Different doses of fertilizers showed significant variations in respect of effective tillers/core, plant height and panicle length of rice (Table 8). Among the different doses of fertilizers $F_{1}$ (RDCF) showed the highest (17.0) number of effective tillers/core and plant height (105.5 $\mathrm{cm})$. Similarly increased effective tillers and plant height were also found by Reddy et al. (2005). Significant variation was observed in number of filled grains/panicle of rice. The highest (121.8) number of filled grain/panicle was recorded in $\mathrm{F}_{3}(50 \% \mathrm{RDCF}+2.1$ ton poultry manure/ha) treatment and the lowest (71.00) number of filled grain per panicle was recorded in $T_{0}$ treatment.

Different doses of fertilizers showed significant variations for grain yield (Table 8). Among the different doses of fertilizer treatments, $F_{1}$ (RDCF) gave the highest $(0.046 \mathrm{~kg} /$ core $)$ grain yield which was statistically similar with $F_{3}$ and the lowest $(0.010$ $\mathrm{kg} /$ core) grain yield was observed in $\mathrm{F}_{0}$ treatment. Similarly higher grain yields in similar treatments were obtained in the findings of Miah et al. (2006) and Xu et al. (2008).

Table 8. Effect of fertilizer and manure on the yield and yield parameters of T. Aman rice

\begin{tabular}{cccccccc}
\hline Treatments & $\begin{array}{c}\text { No. effective } \\
\text { tillers/core }\end{array}$ & $\begin{array}{c}\text { Plant height } \\
(\mathrm{cm})\end{array}$ & $\begin{array}{c}\text { Panicle } \\
\text { length }(\mathrm{cm})\end{array}$ & $\begin{array}{c}\text { No. of filled } \\
\text { grains/panicle }\end{array}$ & $\begin{array}{c}1000 \text { grain } \\
\text { wt. }(\mathrm{g})\end{array}$ & $\begin{array}{c}\text { Straw yield } \\
(\mathrm{kg} / \mathrm{core})\end{array}$ & $\begin{array}{c}\text { Grain yield } \\
(\mathrm{kg} / \mathrm{core})\end{array}$ \\
\hline $\mathrm{F}_{0}$ & $6.3 \mathrm{c}$ & $85.3 \mathrm{~b}$ & $21.2 \mathrm{~b}$ & $71.0 \mathrm{~b}$ & $22.30 \mathrm{~b}$ & $0.011 \mathrm{c}$ & $0.010 \mathrm{c}$ \\
$\mathrm{F}_{1}$ & $17.0 \mathrm{a}$ & $105.6 \mathrm{a}$ & $23.7 \mathrm{a}$ & $114.2 \mathrm{a}$ & $23.57 \mathrm{a}$ & $0.053 \mathrm{a}$ & $0.046 \mathrm{a}$ \\
$\mathrm{F}_{2}$ & $14.3 \mathrm{~b}$ & $100.2 \mathrm{a}$ & $23.4 \mathrm{ab}$ & $112.8 \mathrm{a}$ & $23.70 \mathrm{a}$ & $0.039 \mathrm{a}$ & $0.038 \mathrm{~b}$ \\
$\mathrm{~F}_{3}$ & $14.8 \mathrm{ab}$ & $102.7 \mathrm{a}$ & $23.6 \mathrm{a}$ & $121.8 \mathrm{a}$ & $23.53 \mathrm{a}$ & $0.045 \mathrm{a}$ & $0.041 \mathrm{ab}$ \\
$\mathrm{SE}( \pm)$ & 0.55 & 2.15 & 0.50 & 4.61 & 0.26 & 0.003 & 0.50 \\
\hline
\end{tabular}

In a column figures with dissimilar letter differ significantly as per DMRT at 5\% level of significance.

Significant variation was observed in the straw yield of rice when different doses of fertilizer were applied (Table 8$)$. The highest straw yield $(0.053 \mathrm{~kg} /$ core $)$ was recorded in $\mathrm{F}_{1}$ (RDCF) treatment which was statistically similar with the $F_{2}$ and $F_{3}$ treatments and lowest $(0.011$ $\mathrm{kg} / \mathrm{core}$ ) straw yield was recorded in the $\mathrm{F}_{0}$ treatment. 
The combined effect of different doses of fertilizer and soils on the number of effective tillers/core and plant height of rice were significantly different (Table 9). The higher number of effective tillers/core (18.0) and plant height $(106.48 \mathrm{~cm})$ of rice were recorded with the treatment combination $\mathrm{S}_{2} \mathrm{~F}_{1}$ (Sonargaon Soil + RDCF) which was statically similar to $\mathrm{S}_{1} \mathrm{~F}_{1} \mathrm{~S}_{2} \mathrm{~F}_{3}, \mathrm{~S}_{2} \mathrm{~F}_{2}$ treatment combination. The lowest (6.33) number of effective tillers/core and plant height was found in $\mathrm{S}_{1} \mathrm{~F}_{0}$ (SAU Soil + control treatment) treatment combination.

Combined application of different doses of fertilizer and soils had insignificant variation on the panicle length, number of filled grain/panicle, straw and grain yield of rice (Table 9). The highest (126.0) number of filled grain per panicle of rice was recorded with the treatment combination $\mathrm{S}_{2} \mathrm{~F}_{3}$ (Sonargaon Soil $+50 \%$ RDCF +2.1 ton poultry manure/ha.) and the lowest (71.00) number of filled grain was found in $\mathrm{S}_{1} \mathrm{~F}_{0}$ (SAU Soil + No fertilizer) and $\mathrm{S}_{2} \mathrm{~F}_{0}$ (Sonargaon Soil + No fertilizer) treatment combination. The highest 1000 grain wt. of rice $(24.3 \mathrm{~g})$ was recorded with the treatment combination $\mathrm{S}_{2} \mathrm{~F}_{2}$ (Sonargaon Soil $+50 \% \mathrm{RDCF}+5$ ton cowdung/ha) and the lowest 1000-grain wt. (22.87 g) was found in $\mathrm{S}_{1} \mathrm{~F}_{0}$ (SAU Soil + control treatment) treatment combination. The higher $(0.049 \mathrm{~kg} / \mathrm{core})$ grain yield and straw yield $(0.056 \mathrm{~kg} /$ core $)$ of rice were recorded with the treatment combination $\mathrm{S}_{2} \mathrm{~F}_{1}$ (Sonargaon Soil $+\mathrm{RDCF}$ ) and the lower grain yield $(0.010 \mathrm{~kg} /$ core $)$ and straw yield were found in $\mathrm{S}_{1} \mathrm{~F}_{0}$ (SAU Soil + control treatment) treatment combination.

Table 9. Interaction effect of fertilizer and soils on the yield parameters and yield of T. Aman rice

\begin{tabular}{cccccccc}
\hline Treatments & $\begin{array}{c}\text { No. of effective } \\
\text { tillers/core }\end{array}$ & $\begin{array}{c}\text { Plant height } \\
(\mathrm{cm})\end{array}$ & $\begin{array}{c}\text { Panicle } \\
\text { length }(\mathrm{cm})\end{array}$ & $\begin{array}{c}\text { No. of filled } \\
\text { grain/panicle }\end{array}$ & $\begin{array}{c}\text { 1000 grain } \\
\text { wt. }(\mathrm{g})\end{array}$ & $\begin{array}{c}\text { Straw yield } \\
(\mathrm{kg} / \mathrm{core})\end{array}$ & $\begin{array}{c}\text { Grain yield } \\
(\mathrm{kg} / \mathrm{core})\end{array}$ \\
\hline $\mathrm{S}_{1} \mathrm{~F}_{0}$ & $6.3 \mathrm{~d}$ & $82.3 \mathrm{c}$ & 21.1 & 71.0 & 22.87 & 0.010 & 0.010 \\
$\mathrm{~S}_{1} \mathrm{~F}_{1}$ & $16.0 \mathrm{ab}$ & $104.7 \mathrm{a}$ & 23.6 & 113.3 & 23.93 & 0.050 & 0.044 \\
$\mathrm{~S}_{1} \mathrm{~F}_{2}$ & $14.3 \mathrm{bc}$ & $99.8 \mathrm{ab}$ & 22.9 & 107.0 & 23.13 & 0.035 & 0.037 \\
$\mathrm{~S}_{1} \mathrm{~F}_{3}$ & $14.0 \mathrm{bc}$ & $102.1 \mathrm{a}$ & 23.8 & 117.7 & 23.87 & 0.041 & 0.041 \\
$\mathrm{~S}_{2} \mathrm{~F}_{0}$ & $6.3 \mathrm{~d}$ & $88.3 \mathrm{bc}$ & 21.4 & 71.0 & 23.73 & 0.012 & 0.011 \\
$\mathrm{~S}_{2} \mathrm{~F}_{1}$ & $18.0 \mathrm{a}$ & $106.5 \mathrm{a}$ & 23.8 & 115.0 & 23.20 & 0.056 & 0.049 \\
$\mathrm{~S}_{2} \mathrm{~F}_{2}$ & $13.0 \mathrm{c}$ & $100.6 \mathrm{ab}$ & 23.9 & 118.7 & 24.27 & 0.029 & 0.039 \\
$\mathrm{~S}_{2} \mathrm{~F}_{3}$ & $15.7 \mathrm{bc}$ & $103.2 \mathrm{a}$ & 23.4 & 126.0 & 23.20 & 0.036 & 0.040 \\
$\mathrm{SE}( \pm)$ & 0.78 & 3.04 & $\mathrm{NS}$ & $\mathrm{NS}$ & 0.35 & $\mathrm{NS}$ & $\mathrm{NS}$ \\
\hline
\end{tabular}

In a column figure(s) with dissimilar letter differ significantly as per DMRT at 5\% level of significance.

\section{Conclusion}

Higher $\mathrm{N}$ and $\mathrm{K}$ leaching were obtained in the undisturbed column where chemical fertilizers were used for $\mathrm{T}$. aman rice cultivation. Applications of organic plus inorganic fertilizer are recommended for reducing $\mathrm{N}$ and $\mathrm{K}$ leaching and increasing $\mathrm{T}$. Aman rice yield. Higher $\mathrm{P}$ and $\mathrm{K}$ leaching were observed during 30 to $40 \mathrm{DAT}$, so $\mathrm{K}$ and $\mathrm{P}$ fertilizer may be applied in split for reducing leaching loss through the soil column and increasing utilization in rice growth and yield.

\section{Acknowledgement}

The authors gratefully acknowledge the financial support of Ministry of Science and Technology to conduct this research.

\section{References}

Anderson, B.H. and Magdoff, F.R. 2005.Relative movement and soil fixation of soluble organic and inorganic phosphorus. J Environ Qual. 34(6): 2228-33.

Bouyoucos, G.J. 1926. Hydrometer method improved for making particle size analysis of soils. Agron. J. 54: 4661-4665.

Gomez, K.A. and Gomez, A. A. 1984.Statistical procedures for Agricultural Research.Jhon Wiley and Sons, New York.

Jalali, M. and Rowell, D. 2009. Dissplacement studies on leaching of potassium. Environ. Geo. 57(1): 4148-4155.

Jackson, M.L. 1962. Soil Chemical Analysis. Constable and Co. Ltd London, First Print.
Miah, M.A.M., Ishaque, M. and Saha, P.K. 2006. Integrated nutrient management for improving soil health and rice production. Proc. of twenty first BRRI-DAE joint workshops on bridging the rice yield gap for food security. BRRI, Gazipur, Bangladesh, 19-21 Sept., paper 11: 1-15.

Olsen, S.R., Cole, C.V., Watanabe, F.S. and Dean, L.A. 1954. Estimation of available phosphorus in soils by extraction with sodium bicarbonate, U.S. Dept. Agric. Circ., p. 929.

Page, A.L., Miller, R.H. and Keeney, D.R. (ed). 1982. Methods of analysis part 2, Chemical and Microbiological Properties, Second Edition American Society of Agronomy, Inc., Soil Science Society of American Inc. Madson, Wisconsin, USA. pp. 403-430.

Reddy, B.G.M., Pattar, P.S. and Kuchanur, P.H. 2005. Response of rice to poultry manure and graded levels of NPK under irrigated conditions. Oryza, Association of Rice Research Workers, Central Rice Research Institute, Cuttack, India 42(2): 109-111.

Walkley, A. and Black, D.R. 1935.An examination of the digestion method for determining soil organic matter and proposed modification of the chronic acid titration method. Soil Sci. 37: 29-38.

Xu, M.G., Li, D.C., Li, J.M., Qin, D.Z., Yagikazuyuki and Hosen, Y. 2008. Effects of organic manure application with chemical fertilizers or Nutrient Absorption and yield of Rice in Hunan of Southern China. Agric. Sci. in China.7 (10): 1245-1252.

Yang, C.M., Yang, L., Yang, Y. and Ouyang, Z. 2004. Rice root growth and nutrient uptake as influenced by organic manure in continuously and alternately flooded paddy soils. Agricultural Water Management. 70 (1): 67-81. 
